\title{
Influence of Pre- and Postharvest Summer Pruning on the Growth, Yield, Fruit Quality, and Carbohydrate Content of Early Season Peach Cultivars
}

\begin{abstract}
Ali Ikinci
Department of Horticulture, Faculty of Agriculture, Harran University, 63330 Sanliurfa, Turkey

Correspondence should be addressed to Ali Ikinci; aliikinci@harran.edu.tr

Received 6 November 2013; Revised 20 January 2014; Accepted 21 January 2014; Published 10 March 2014

Academic Editor: Yuxin Miao

Copyright (C) 2014 Ali Ikinci. This is an open access article distributed under the Creative Commons Attribution License, which permits unrestricted use, distribution, and reproduction in any medium, provided the original work is properly cited.

Winter and summer pruning are widely applied processes in all fruit trees, including in peach orchard management. This study was conducted to determine the effects of summer prunings (SP), as compared to winter pruning (WP), on shoot length, shoot diameter, trunk cross sectional area (TCSA) increment, fruit yield, fruit quality, and carbohydrate content of two early ripening peach cultivars ("Early Red" and "Maycrest") of six years of age, grown in semiarid climate conditions, in 2008 to 2010 . The trees were grafted on GF 677 rootstocks, trained with a central leader system, and spaced $5 \times 5 \mathrm{~m}$ apart. The SP carried out after harvesting in July and August decreased the shoot length significantly; however, it increased its diameter. Compared to 2009, this effect was more marked in year 2010. In general, control and winter pruned trees of both cultivars had the highest TCSA increment and yield efficiency. The SP increased the average fruit weight and soluble solids contents (SSC) more than both control and WP. The titratable acidity showed no consistent response to pruning time. The carbohydrate accumulation in shoot was higher in WP and in control than in SP trees. SP significantly affected carbohydrate accumulation; postharvest pruning showed higher carbohydrate content than preharvest pruning.
\end{abstract}

\section{Introduction}

Small, dwarf, or size controlled fruit trees provide easier pruning, thinning, spraying, and harvesting and could lead to production of high-grade fruit at lower production cost [1]. To induce dwarfing, fruit growers can use dwarfing rootstocks. However, dwarfing rootstocks are not yet available for peaches, like apple [2].

Summer pruning has long been used as a management method for fruit trees. It was shown to be a valuable method of controlling tree growth [3-7], increasing flowering [4], increasing fruit color $[1,3,7,8]$, increasing soluble solids concentration (SSC) $[5-7,9]$, increasing flower bud formation [10], and decreasing titratable acid content (TA) $[1,6,7]$. Disadvantage of summer pruning include reduced cold hardiness of flower buds [11], delayed defoliation [7, 11], carbohydrate levels in the tree [11-13], fruit size [2, 8, 14, 15], and trunk enlargement [14].
The above mentioned differences can be attributed to differences in timing and severity of pruning, and because, in some cases, summer pruning was used as a replacement for dormant pruning rather than as a supplement.

Summer pruning of peach trees, at a time when stems, fruits, and roots are still growing, potentially could remove $35 \%$ to $45 \%$ of the total tree leaf area. The significant loss of leaf area on summer-pruned trees may lead to a reduction in the carbohydrate and nutrient element concentrations in remaining tissues and thus limit the growth of trees. Summer pruning decreased carbohydrate concentration in stems and roots of mulberry and reduced the leaf carbohydrate concentrations by about $30 \%$ during the 45 -day period after pruning [16]. In sweet cherry, after summer pruning, the middle and upper parts of the trunk contained the highest concentrations of starch and soluble sugars. One year after summer pruning, the level of carbohydrates in the trunk was lower compared with unpruned trees [12]. Total carbohydrate 
contents of perennial parts of trees in the temperate zone reach a maximum in the autumn, begin to decrease in late winter, and decrease rapidly in early spring $[12,17]$.

Previous studies have shown that pruning results in quantitative changes in carbohydrate reserves. Pruning affects the level of reserves by elimination of storage sites [18]. Pruning has been also reported to slow down the reconstitution of reserves or to contribute to their depletion [19].

Carbohydrates are an essential source of reserve energy in temperate zone trees and other perennial plants. They can be mobilised for metabolism or translocated to other plant organs. The concentration and localization of carbohydrates, such as sugars and starches, within tissues are affected by many factors, such as temperature, moisture, light, pruning, and time of planting [20].

The aim of this study was to determine the effect of preharvest (May and June) and postharvest (July and August) summer pruning on accumulation of carbohydrates in shoots, vegetative and reproductive growth, fruit quality, and yield efficiency of the two early ripening peach cultivars "Early Red" and "Maycrest" on GF 677 rootstock.

\section{Materials and Methods}

This research was conducted during the 2008-2010 growing seasons at the Harran University (Şanlıurfa, Turkey) Pome Fruit Research Station $\left(37^{\circ} 19^{\prime} \mathrm{N} ; 38^{\circ} 96^{\prime} \mathrm{E} ; 520 \mathrm{~m}\right.$ a.s.l.). Şanliurfa province has continental climatic features; it is very cold and wet in the winter and very hot and dry in the summer. During the experiment, the air temperatures were in average of $29.6^{\circ} \mathrm{C}$ in summer and $6.4^{\circ} \mathrm{C}$ in winter, while annual precipitation ranged between 428 and $486 \mathrm{~mm}$, mainly concentrated between the months of November and April. The soil in the orchard $(0-40 \mathrm{~cm})$ is loamy with $40 \%$ clay, $33.2 \%$ silt, and $21.4 \%$ sand, low in organic matter $(1.1 \%)$, and rich in calcium carbonate contents $(25 \%)$ and has a high $\mathrm{pH}(8.4)$ [21].

2.1. Plant Materials, Treatment, and Measurement. Summer pruning was performed on six-year-old early ripening trees of "Early Red" and "Maycrest" peach on GF 677 rootstock. Trees were planted in 2004 at a $5 \times 5 \mathrm{~m}\left(400\right.$ trees ha $\left.^{-1}\right)$ spacing and trained to a central leader system, drip irrigated, and managed using standard cultural practices.

Trees were selected for uniformity based on tree size, trunk circumference, and total fruit count. Trees were $\approx 2.5$ to $3.0 \mathrm{~m}$ high and 2.5 to $3.5 \mathrm{~m}$ wide. All trees had been uniformly pruned during previous dormant season. Dormant pruning was performed in February and consisted of heading vertical shoots to maintain tree height $2.5 \mathrm{~m}$, thinning cuts, and removal of vigorous watersprouts. During 2008 to 2010, the following treatments were applied to trees: (a) unpruned control; (b) pruned in May 7; (c) pruned June 7; (d) pruned July 7; and (e) pruned August 7.

All summer-pruned trees received normal winter hand pruning during February 2009 and February 2010. These trees are named the SP and WP, respectively. Summer pruning consisted of heading back of current season shoots to about
$10 \mathrm{~cm}$ length and removal of vigorous shoots $[7,13,22]$. $\approx 50 \%$ of the current season's shoot growth was removed by each of summer pruning treatments. In addition, diseased and broken branches were also removed from trees $[1,7,11,23]$. Control trees received only light dormant (winter) pruning with thinning-out cuts. The fresh weight of prunings $\left(\mathrm{kg}\right.$ tree $\mathrm{e}^{-1}$ ) was determined for all treatments at each pruning date. In 2008, all SP treatments on the trees and presummer pruning (SP) have been considered as applications and all data obtained are not included in the calculations. Treatments were arranged in a randomized complete block design with four single-tree replications per treatment.

Ten shoots at $1.5 \mathrm{~m}$ above ground were selected from around each tree for growth measurements. The terminal and lateral shoots were measured prior to summer pruning treatments and in November. Shoot diameter was measured at $2 \mathrm{~cm}$ from the shoot base. For calculating the trunk crosssectional area (TCSA), trunk circumference about $20 \mathrm{~cm}$ above the graft union was measured with a hand caliper at the end of the growing season and converted to TCSA in $\mathrm{cm}^{2}$. Yields per tree were recorded in years 2009 and 2010. Finally, yield efficiency was measured as yield per tree divided to TCSA in late growing season (yield per tree/TCSA). The TCSA and shoot growth were determined by Marini [11].

Ten fruits per tree were randomly selected and used to determine mean fruit weight, total soluble solids content (SSC), and titratable acidity (TA). The SSC (\%) was measured with a hand Atago refractometer. TA of fruit juice was measured by titrating fruit juice against $0.1 \mathrm{~N} \mathrm{NaOH}$ at $\mathrm{pH}$ 8.1 and was expressed as percent malic acid.

2.2. Carbohydrates in the Bark of Dormant Shoots. After summer pruning in 2009 and 2010, a random sample of 12 annual shoots was collected (at the beginning of rest period/in December) from each tree. Phloem with cambium was used and prepared for analyses. Barks with a knife peeled branches were dried at $70^{\circ} \mathrm{C}$ for at least $72 \mathrm{hr}$ and then frozen at $-18^{\circ} \mathrm{C}$, lyophilized, and stored in a desiccators at $-18^{\circ} \mathrm{C}$ for carbohydrate analysis. The reduced sugar, total sugar, and starch contents were determined by dinitrophenol and anthron methods [24].

2.3. Statistical Analyses. Data were evaluated by analysis of variance with Minitab 16.1.0 Statistics software package. When the $F$-test was significant, means were separated by Duncan's multiple range test (DMRT) at $P<0.05$. An arcsine square-root transformation was performed on percent data.

\section{Results}

3.1. Average Fresh Weight of Prunings ( $\left.\mathrm{kg} \mathrm{tree}^{-1}\right)$. Generally, more fresh weight was removed as the pruning date was delayed from May to August (Figure 1). The least prunings were found in the control trees in 2009 and 2010 in Early Red cultivar. Whereas, summer pruning done in May of both years in Maycrest peach cultivar is the practice from which the least prunings were obtained. 


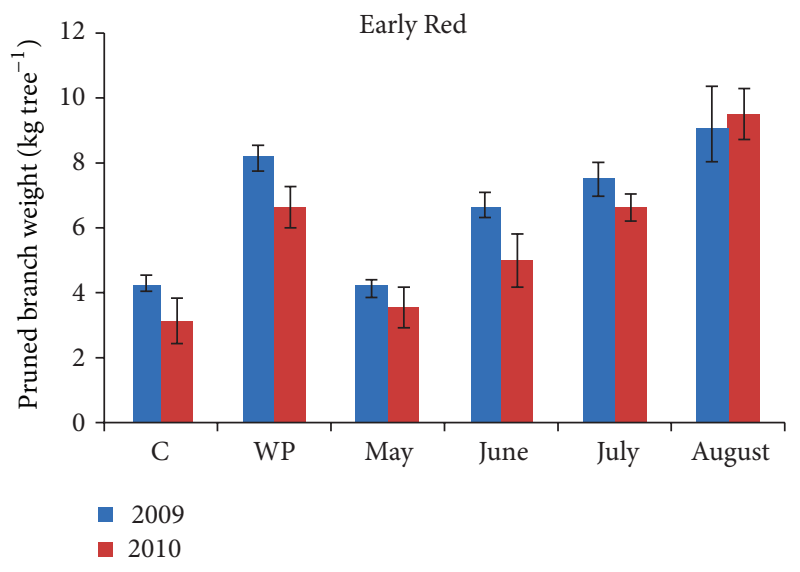

(a)

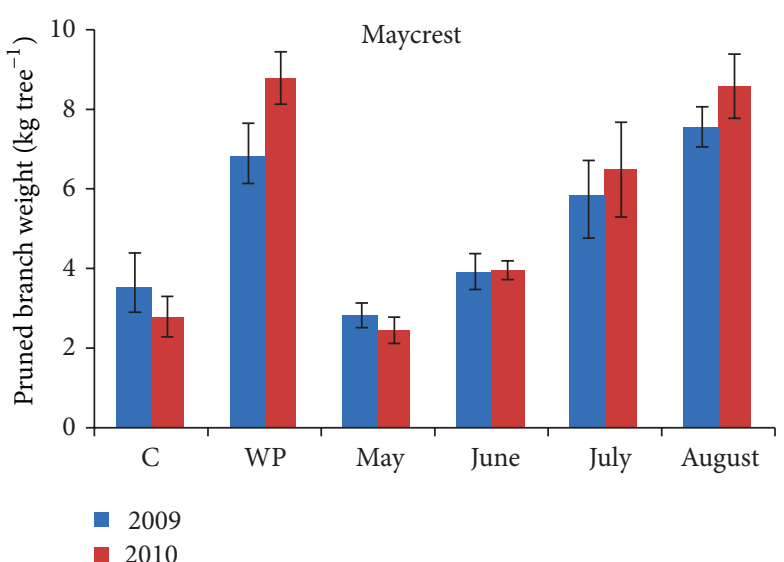

(b)

FIGURE 1: Effect of summer and winter pruning on pruned shoot weight of peach trees in 2009-2010. Vertical bars represent SE $(n=6)$.

TABLE 1: The influence of summer and winter pruning treatments on average shoot length and shoot diameter.

\begin{tabular}{|c|c|c|c|c|c|c|c|c|}
\hline \multirow{3}{*}{ Pruning treatment } & \multicolumn{4}{|c|}{ Early Red } & \multicolumn{4}{|c|}{ Maycrest } \\
\hline & \multicolumn{2}{|c|}{ Average shoot length $(\mathrm{cm})$} & \multicolumn{2}{|c|}{ Shoot diameter (mm) } & \multicolumn{2}{|c|}{ Average shoot length $(\mathrm{cm})$} & \multicolumn{2}{|c|}{ Shoot diameter $(\mathrm{mm})$} \\
\hline & 2009 & 2010 & 2009 & 2010 & 2009 & 2010 & 2009 & 2010 \\
\hline Control & $73.36 \mathrm{a}^{\mathrm{z}}$ & $67.12 \mathrm{a}$ & $12.1 \mathrm{a}$ & $11.4 \mathrm{~b}$ & $70.88 \mathrm{a}$ & $72.17 \mathrm{a}$ & $12.2 \mathrm{ab}$ & $14.6 \mathrm{a}$ \\
\hline WP & $68.64 \mathrm{a}$ & $61.35 \mathrm{~b}$ & $10.6 \mathrm{~b}$ & $12.3 \mathrm{a}$ & $75.08 \mathrm{ab}$ & $69.38 \mathrm{ab}$ & $13.5 \mathrm{a}$ & $12.4 \mathrm{~b}$ \\
\hline SP-May & $60.89 \mathrm{~b}$ & $54.74 \mathrm{bc}$ & $9.2 \mathrm{bc}$ & $10.7 \mathrm{bc}$ & $66.38 \mathrm{~b}$ & $52.72 \mathrm{~b}$ & $10.7 \mathrm{~b}$ & $11.4 \mathrm{bc}$ \\
\hline SP-June & $55.15 \mathrm{bc}$ & $50.62 c$ & $8.6 \mathrm{c}$ & $10.0 \mathrm{c}$ & $54.86 \mathrm{c}$ & $49.50 \mathrm{~b}$ & $9.9 \mathrm{c}$ & $10.2 \mathrm{c}$ \\
\hline SP-July & $47.84 \mathrm{c}$ & $40.08 \mathrm{~d}$ & $9.2 \mathrm{bc}$ & $10.2 \mathrm{bc}$ & $45.71 \mathrm{c}$ & $44.43 \mathrm{~b}$ & $9.4 \mathrm{c}$ & $9.8 \mathrm{c}$ \\
\hline SP-August & $41.45 \mathrm{c}$ & $46.36 \mathrm{~cd}$ & $8.7 \mathrm{c}$ & $9.7 \mathrm{c}$ & $49.27 \mathrm{c}$ & $45.48 \mathrm{~b}$ & $9.6 \mathrm{c}$ & $9.4 \mathrm{c}$ \\
\hline
\end{tabular}

${ }^{\mathrm{z}}$ Mean separation within columns by Duncan's multiple range test at $5 \%$ level.

3.2. Average Shoot Length and Diameter. Pruning treatments had significant effect on the enlargement of shoot length and shoot diameter in both peach varieties (Table 1). The longest shoot enlargement of Early Red and Maycrest peach was detected in trees with control and WP treatment in 2009 and 2010. It was found that the length of the shoot obtained after the SP conducted in May on both peach varieties was longer compared to other SP treatments. In the second year, it was found that the shoot growing significantly decreased in WP and SP treatments compared to the first year, except for control trees. It was also noticed that postharvest SP conducted on peach trees had a significant effect on reducing the rate of shoot enlargement of trees compared to preharvest SP.

The highest shoot diameter enlargement was detected in trees with control and WP treatment in both peach varieties, similar to shoot length enlargement. In the second year of SP treatments, shoot diameter enlargement of Early Read peach trees increased, compared to the first year. However, this increase was observed in trees with SP treatment in May, June, and July for Maycrest trees. In general, it was found that SP treatments in 2010 led to a significant increase in shoot diameter compared to the first year.
3.3. Trunk Cross Sectional Area (TCSA). The effects of pruning on TCSA $\left(\mathrm{cm}^{2}\right)$, yield $\left(\mathrm{kg} \mathrm{tree}^{-1}\right)$, and yield efficiency $\left(\mathrm{kg} \mathrm{cm}{ }^{-2}\right.$ TCSA) of Early Read and Maycrest peach cultivars are presented in Table 2. The effects of pruning treatments were found to be significant on TCSA development of peach trees in both of the years and the effect of pruning by varieties and years varied. In Early Read cultivar, the highest TCSA enlargement was obtained from SP-August and control in 2009 and from control and SP-May treatments in 2010. In Maycrest variety, the highest TCSA enlargement was obtained from trees with WP treatments in both of the years. In Early Read, the lowest TCSA enlargement was obtained from SP-June and WP in 2009 and from SP-June treatments in 2010 and in Maycrest, the lowest TCSA enlargement was obtained from SP-July treatments in both of the years.

3.4. Yield and Yield Efficiency. Pruning treatments had statistically significant effects on the fruit production of peach trees (Table 2). In Early Read and Maycrest varieties, the highest fruit production was obtained from control trees in both of the years. In Maycrest variety, following control trees, the highest production was obtained from WP treatment. 
TABLE 2: The effects of summer and winter pruning time on TCSA, yield, and yield efficiency of "Early Red" and "Maycrest" peach cultivars.

\begin{tabular}{|c|c|c|c|c|c|c|}
\hline \multirow{2}{*}{ Pruning treatment } & \multicolumn{2}{|c|}{$\operatorname{TCSA}\left(\mathrm{cm}^{2}\right)$} & \multicolumn{2}{|c|}{ Yield $\left(\mathrm{kg}\right.$ tree $\left.^{-1}\right)$} & \multicolumn{2}{|c|}{ Yield efficiency $\left(\mathrm{kg} \mathrm{cm}^{-2}\right.$ TCSA) } \\
\hline & 2009 & 2010 & 2009 & 2010 & 2009 & 2010 \\
\hline \multicolumn{7}{|c|}{ Early Red } \\
\hline Control & $156.78 \mathrm{a}^{\mathrm{z}}$ & $190.23 \mathrm{a}$ & $61.98 \mathrm{a}$ & $75.92 \mathrm{a}$ & $0.40 \mathrm{a}$ & $0.40 \mathrm{a}$ \\
\hline WP & $140.11 \mathrm{~b}$ & $172.79 \mathrm{~b}$ & $43.62 \mathrm{bc}$ & $57.11 \mathrm{ab}$ & $0.31 \mathrm{~b}$ & $0.33 \mathrm{~b}$ \\
\hline SP-May & $151.27 \mathrm{ab}$ & $178.17 \mathrm{ab}$ & $38.98 \mathrm{c}$ & $46.13 \mathrm{~b}$ & $0.26 \mathrm{c}$ & $0.26 \mathrm{c}$ \\
\hline SP-June & $137.71 \mathrm{~b}$ & $160.96 \mathrm{c}$ & $52.48 \mathrm{ab}$ & $53.92 \mathrm{ab}$ & $0.38 \mathrm{ab}$ & $0.34 \mathrm{~b}$ \\
\hline SP-July & $146.91 \mathrm{ab}$ & $167.12 \mathrm{~b}$ & $41.54 \mathrm{c}$ & $45.71 \mathrm{~b}$ & $0.28 \mathrm{bc}$ & $0.27 \mathrm{c}$ \\
\hline SP-August & $159.88 \mathrm{a}$ & $175.94 \mathrm{a}$ & $49.48 \mathrm{~b}$ & $51.02 \mathrm{ab}$ & $0.31 \mathrm{~b}$ & $0.29 \mathrm{c}$ \\
\hline \multicolumn{7}{|c|}{ Maycrest } \\
\hline Control & $130.7 \mathrm{ab}$ & $164.09 \mathrm{~b}$ & $75.98 \mathrm{a}$ & $68.24 \mathrm{a}$ & $0.58 \mathrm{a}$ & $0.42 \mathrm{a}$ \\
\hline WP & $146.22 \mathrm{a}$ & $175.29 \mathrm{a}$ & $65.24 \mathrm{ab}$ & $63.09 \mathrm{ab}$ & $0.45 \mathrm{ab}$ & $0.36 \mathrm{c}$ \\
\hline SP-May & $126.67 \mathrm{~b}$ & $152.06 \mathrm{c}$ & $53.12 \mathrm{~b}$ & $52.23 \mathrm{c}$ & $0.42 \mathrm{~b}$ & $0.34 \mathrm{c}$ \\
\hline SP-June & $129.64 \mathrm{~b}$ & $159.08 \mathrm{bc}$ & $53.94 \mathrm{~b}$ & $62.68 \mathrm{ab}$ & $0.42 \mathrm{~b}$ & $0.39 \mathrm{~b}$ \\
\hline SP-July & $119.29 \mathrm{c}$ & $142.37 \mathrm{~d}$ & $50.4 \mathrm{~b}$ & $57.79 \mathrm{~b}$ & $0.42 \mathrm{~b}$ & $0.41 \mathrm{ab}$ \\
\hline SP-August & $134.73 \mathrm{ab}$ & $163.15 \mathrm{~b}$ & $62.52 \mathrm{ab}$ & $59.93 \mathrm{~b}$ & $0.46 \mathrm{ab}$ & $0.37 \mathrm{~b}$ \\
\hline
\end{tabular}

${ }^{\mathrm{z}}$ Mean separation within columns by Duncan's multiple range test at $5 \%$ level.

In Early Read, the effects of pruning treatments on fruit production differed by treatment period.

There were statistically significant differences $(P<$ 0.05 ) among applications on yield as determined by TCSA $\left(\mathrm{kg} \cdot \mathrm{cm}^{-2}\right)$ (Table 2). Similar to fructification values, the highest yield efficiency value of both peach trees was obtained from control trees which were not pruned. It was observed that yield efficiency values of trees with SP treatments were lower than those of trees with control and WP treatment and SP-May had low effect on production value. On the other hand, it was found that yield efficiency value of both preach varieties in 2010 was lower compared to the year 2009.

3.5. Average Fruit Weight. Early Read and Maycrest varieties were harvested in 26 June and 07 June in 2009 and 21 June and 1 June in 2010, respectively. Pruning treatments had significant effect on average fruit weight of peach trees varieties (Table 3). In Early Read, the heaviest fruits were obtained from SP-May treatment in 2009 and 2010 (117.46 g and $122.87 \mathrm{~g}$, resp.). In Maycrest, the heaviest fruits were obtained from SP-May treatment in 2009 (121.90 g) and from SP-June treatment in 2010 (124.75 g). In general, the smallest fruits were obtained from control trees in both peach varieties.

3.6. Soluble Solids. Pruning treatments did not affect the SSC of Early Read peach fruits in 2009 and 2010, whereas SSC in Maycrest was affected by pruning treatment only in 2009 (Table 3). Data from this study confirm that SP or WP had inconsistent effects on peach fruit SSC. As can be seen in Table 3, in the second year of pruning treatments, an increase was observed in WP and some SP treatments of the SSC compared to the first year.
3.7. Titratable Acidity. Pruning treatments conducted in different periods had significant effects on TA (\%) of fruits of Maycrest variety in 2009 and 2010 and of Early Read in 2010 (Table 3 ). The TA of peach varieties differed by pruning period and years to a great extent. The TA analyses results, as seen in Table 3, was lower in 2010 compared to the year 2009.

3.8. Carbohydrate Concentrations. Pruning had a significant effect on starch and total carbohydrate contents of two peach cultivars (Table 4). The effects of SP or WP on carbohydrate concentrations of peach trees have been quite variable.

3.9. The Effect of Pruning on Starch Content (\%). Pruning applications significantly affected starch contents of peach shoots (Table 4). In Early Read variety, the highest starch level was found in trees with control $(5.50 \%)$ and WP treatment (5.11\%) in 2009 and in control trees (5.70\%) in 2010. In Maycrest variety, the highest starch value was obtained from trees with WP treatment (5.50\% and 7.30\%, resp.) in 2009 and 2010. In Early Read variety, the lowest starch value was obtained from SP-June (2.50\%) treatment in both of the years. In Maycrest variety, the lowest value was obtained from SPMay (3.22\%) in 2009 and from SP-July (4.95\%) in 2010.

3.10. The Effect of Pruning on Total Extracted Carbohydrate Concentrations. As for total carbohydrate concentrations ( $\mathrm{CHO}$ ) calculated by adding starch concentrations and reducing sugars, it was found that pruning treatments had significant effect on peach trees (Table 4). Although there were variables by years in both peach varieties, the highest $\mathrm{CHO}$ level was obtained from trees in control and WP treatment. In general, it was found that SP treatments decrease $\mathrm{CHO}$ level in peach shoots and this decrease was in 
TABLE 3: Average fruit weight (g), soluble solids (\%), and titratable acidity (\%) of peaches as influenced by summer and winter pruning.

\begin{tabular}{|c|c|c|c|c|c|c|}
\hline \multirow{2}{*}{ Pruning treatment } & \multicolumn{2}{|c|}{ Average fruit weight (g/fruit) } & \multicolumn{2}{|c|}{ Soluble solids content (\%) } & \multicolumn{2}{|c|}{ Titratable acidity (\%) } \\
\hline & 2009 & 2010 & 2009 & 2010 & 2009 & 2010 \\
\hline \multicolumn{7}{|c|}{ Early Red } \\
\hline Control & $78.74 \mathrm{~d}^{\mathrm{z}}$ & $84.58 \mathrm{c}$ & 14.50 & 14.75 & $0.69 \mathrm{bc}$ & 0.62 \\
\hline WP & $85.97 \mathrm{c}$ & $97.27 \mathrm{bc}$ & 14.65 & 15.25 & $0.65 c$ & 0.63 \\
\hline SP-May & $117.46 \mathrm{a}$ & $122.87 \mathrm{a}$ & 15.00 & 15.50 & $0.71 \mathrm{~b}$ & 0.64 \\
\hline SP-June & $99.46 \mathrm{bc}$ & $105.84 \mathrm{~b}$ & 15.75 & 15.50 & $0.77 \mathrm{a}$ & 0.64 \\
\hline SP-July & $110.05 \mathrm{~b}$ & $100.47 \mathrm{~b}$ & 15.00 & 14.75 & $0.73 \mathrm{ab}$ & 0.66 \\
\hline SP-August & $92.79 \mathrm{c}$ & $115.89 \mathrm{ab}$ & 15.30 & 15.00 & $0.73 \mathrm{ab}$ & 0.64 \\
\hline \multicolumn{7}{|c|}{ Maycrest } \\
\hline Control & $87.30 \mathrm{~b}$ & $99.79 \mathrm{~b}$ & $14.60 \mathrm{ab}$ & 15.00 & $0.67 \mathrm{a}$ & $0.58 \mathrm{a}$ \\
\hline WP & $100.28 \mathrm{~b}$ & $117.92 \mathrm{ab}$ & $14.33 \mathrm{a}$ & 15.60 & $0.64 \mathrm{ab}$ & $0.59 \mathrm{a}$ \\
\hline SP-May & $121.90 \mathrm{a}$ & $100.36 \mathrm{~b}$ & $14.33 \mathrm{ab}$ & 14.90 & $0.59 \mathrm{bc}$ & $0.54 \mathrm{~b}$ \\
\hline SP-June & $108.17 \mathrm{ab}$ & $124.75 \mathrm{a}$ & $14.67 \mathrm{~b}$ & 15.25 & $0.62 \mathrm{~b}$ & $0.53 \mathrm{~b}$ \\
\hline SP-July & $103.29 \mathrm{ab}$ & $110.58 \mathrm{~b}$ & $15.07 \mathrm{a}$ & 15.70 & $0.57 \mathrm{c}$ & $0.51 \mathrm{~b}$ \\
\hline SP-August & $106.36 \mathrm{ab}$ & $105.05 \mathrm{~b}$ & $15.53 \mathrm{a}$ & 15.20 & $0.56 \mathrm{c}$ & $0.51 \mathrm{~b}$ \\
\hline
\end{tabular}

${ }^{\mathrm{z}}$ Mean separation within columns by Duncan's multiple range test at $5 \%$ level.

TABLE 4: The influence of pruning treatments on concentration of starch and total carbohydrate content of shoot of "Early Red" and "Maycrest" peach cultivars.

\begin{tabular}{lcccccccc}
\hline & \multicolumn{3}{c}{ Early Red } & \multicolumn{3}{c}{ Maycrest } \\
Pruning treatment & \multicolumn{2}{c}{ Starch (\%) } & \multicolumn{2}{c}{ Total extracted CHO (\%) } & \multicolumn{2}{c}{ Starch (\%) } & \multicolumn{2}{c}{ Total extracted CHO (\%) } \\
& 2009 & 2010 & 2009 & 2010 & 2009 & 2010 & 2009 & 2010 \\
\hline Control & $5.50 \mathrm{a}$ & $6.80 \mathrm{a}$ & $8.46 \mathrm{a}$ & $9.96 \mathrm{a}$ & $5.83 \mathrm{a}$ & $6.78 \mathrm{a}$ & $8.62 \mathrm{a}$ & $9.81 \mathrm{a}$ \\
WP & $5.11 \mathrm{ab}$ & $6.50 \mathrm{ab}$ & $7.94 \mathrm{ab}$ & $9.63 \mathrm{ab}$ & $5.55 \mathrm{a}$ & $6.41 \mathrm{ab}$ & $8.57 \mathrm{a}$ & $9.30 \mathrm{ab}$ \\
SP-May & $4.50 \mathrm{c}$ & $5.24 \mathrm{c}$ & $7.03 \mathrm{c}$ & $7.70 \mathrm{c}$ & $4.22 \mathrm{c}$ & $4.85 \mathrm{~d}$ & $6.36 \mathrm{~d}$ & $7.20 \mathrm{~d}$ \\
SP-June & $4.12 \mathrm{~d}$ & $5.17 \mathrm{c}$ & $6.57 \mathrm{c}$ & $7.45 \mathrm{c}$ & $4.70 \mathrm{~b}$ & $4.98 \mathrm{~cd}$ & $7.06 \mathrm{c}$ & $7.42 \mathrm{c}$ \\
SP-July & $4.63 \mathrm{c}$ & $5.94 \mathrm{~b}$ & $7.28 \mathrm{c}$ & $8.67 \mathrm{~b}$ & $4.80 \mathrm{~b}$ & $5.35 \mathrm{c}$ & $7.39 \mathrm{bc}$ & $8.03 \mathrm{c}$ \\
SP-August & $4.72 \mathrm{~b}$ & $6.29 \mathrm{~b}$ & $7.44 \mathrm{~b}$ & $9.10 \mathrm{~b}$ & $5.04 \mathrm{ab}$ & $6.02 \mathrm{~b}$ & $7.67 \mathrm{~b}$ & $8.85 \mathrm{~b}$ \\
\hline
\end{tabular}

${ }^{\mathrm{z}}$ Mean separation within columns by Duncan's multiple range test at $1 \%$ level.

higher amounts in SP-June treatments in Early Read and in SP-May treatments in Maycrest.

\subsection{The Effect of Pruning on Total Extracted Carbohy-} drate Concentrations. As for total carbohydrate concentrations $(\mathrm{CHO})$ calculated by adding starch concentrations and reducing sugars, it was found that pruning treatments had significant effect on peach trees (Table 4). Although there were variables by years in both peach varieties, the highest $\mathrm{CHO}$ level was obtained from trees with control and WP treatment. In general, it was found that SP treatments decrease $\mathrm{CHO}$ level in peach shoots and this decrease was in higher amounts in SP-June treatments in Early Read variety and in SP-May treatments in Maycrest variety.

\section{Discussion}

In the research, all application trees to be pruned in summer were pruned in 2008 at the same date; therefore, prunings values in 2009 were more realistic. Branch weight is much more since the branches, which are removed in summer pruning, include leaves. Taylor and Ferree [25] found that summer pruning reduced whole tree dry weight in proportion to the percentage of shoot removal. If the branch weight obtained from pruning was determined in terms of dry weight in the research, branch weight obtained from winter pruning would be weightier by 2- to 3-fold than the summer pruning from which the prunings at the highest number were obtained. Summer pruning in 2009 in peach trees led to proportional, not numeral, reduction of both summer and winter prunings weights in 2010. The results obtained from the study in terms of prunings' weights received from pruning practices are similar to the results of Miller [10] obtained from apple; Kappel and Bouthillier [26] obtained from peach; İkinci [7] obtained from almond, peach, and apricot; and Hossain et al. [6] obtained from peach. Kappel and Bouthillier [26] stated that fewer prunings were obtained in winter pruning from trees whose summer pruning was done. They stated also that the weight of shoots obtained in summer pruning in the second year was less than the first year.

Pruning treatments conducted on two peach varieties (WP and SP), especially the SP decrease shoot growth significantly. Restricted shoot growth and reduced shoot diameter started to be observed in the second year (Table 1). 
It was found that postharvest or late July-August SP was more effective on slowing down the shoot growth compared to preharvest or early May-SP and June-SP. Studies on peach and apple trees support our research results [1, 6, 7, 9, 14, 27-29].

Increase trunk enlargement of peach trees with control and WP was higher compared to SP. Many other researchers studying on pruning of peach $[7,14,28,30]$ and other tropical fruit varieties reported that SP decreases trunk enlargement compared to WP. However, studies on apple $[25,31]$ suggested that SP has no effect on trunk enlargement.

Although variable results were obtained from SP and WP treatments conducted by years and varieties, the yield efficiency value of trees with control and WP treatments in the first year was higher. Likewise, Daulta et al. [32], Miller [22], Tehrani and Leuty [8], Chitkara et al. [33], Küden and Kaşka [23], İkinci [7], Akçay [34], and Demirtaş et al. [5] all found different results on the effect of pruning on yield and yield efficiency data in different temperate fruit trees. We found that trees with SP had close values to control trees or to those with only WP in terms of yield efficiency values in second year pruning treatments (Table 2).

It was reported in previous pruning studies that summer pruning on apple, almond, peach, and apricot decreases yield efficiency compared to winter pruning. Demirtaş et al. [5] reported that preharvest and postharvest period pruning on "Hacıhaliloğlu" apricot variety improve the yield of trees; yet this increase is not statistically significant. Similarly, Bayazit et al. [3] reported that there is no statistically significant difference between summer-pruned and unpruned trees of peach and some nectarine varieties in terms of yield per tree.

Fruit set of peach trees occurs on one, two, or multiyear branches. The application of WP + SP treatment on peach trees has thinning effect on fruits of trees in the same year. Our findings indicate that if SP treatment is performed on the same trees after WP in preharvest period (e.g., 30 days), nonharvested fruits on the trees grow larger compared to trees on which WP treatment is not applied.

Various researchers studying on pruning explained that SP leads to an increase on the size of fruits as follows. The fruit size distribution effects of SP may be the result of a decrease in total leaf area and, as a result, a decrease in total transpirational loss by tree. Such trees would use less water and be less susceptible to water stress, thereby improving fruit water status and fruit growth rate during Stage III (final swell) when the fruit have a large demand for photosynthates and water [13, 35-37]. There may have been an increase in photosynthate available to fruit of summer-pruned trees due to an increase in photosynthetic photon flux density and/or the removal of competitive sinks, that is, watersprouts. Also, improved light exposure may have strengthened fruit sink activity, thus increasing fruit size [4].

Mika [38] reported that SP does not increase the largeness of fruits; on the contrary, he asserted that formation of smaller fruits results from the $20 \%$ decrease in assimilate amount, due to the reduction of leaves that provide resource for assimilate pool of trees by pruning. Greene and Lord [31] reported that SP reduced apple fruit weight in 1978-1980 and increased it in 1979.
Gür and Prrlak [39] reported that average fruit weight differs between $133.4 \mathrm{~g}$ and $258 \mathrm{~g}$ in 16 peach varieties grafted on peach seedling in Eğirdir conditions in western Turkey. Bayazit et al. [3] reported that average fruit weights of 5 different peach varieties with SP differ between $64.59 \mathrm{~g}$ (Spring Belle) and $95.79 \mathrm{~g}$ (Springcrest). The average fruit weights (minimum: $78.74 \mathrm{~g}$, maximum: $124.75 \mathrm{~g}$ ) obtained in the present study which was conducted in Şanliurfa province under semiarid climate conditions are less than the values in the research conducted by Gür and Pirlak [39] and relatively higher than the results of Bayazit et al. [3] (Table 3).

In pruning treatments conducted on early peach varieties successively in 3 years, SSC values of 2010 were higher than those of 2009. According to earlier studies, Daulta et al. [32], Hossain et al. [40], and Hossain and Mizutani [1] reported that SP applications had increased SSC in peach. However, Niran [15], Miller [10], İkinci [7], and Bayazit et al. [3] reported that SP applications had no significant effect on SSC of fruits in both peach and apple. Marini and Barden [41], Taylor and Ferree [25], Cust and Ferree [42], Miller [22], and Christopher et al. [37] stated that SP applications negatively affected SSC in peach. The reduction in fruit size and fruit soluble solids associated with relatively severe SP is likely due to the reduction in total photosynthetic production of tree resulting in less carbohydrates available for the fruit.

As a result of the effect of pruning treatments, the decrease in TA content of peach fruits in the first year continued in the second year as well. In particular, in the summer pruning trees that made a higher rate reductions were identified (Table 3). Similar to the results of our research, Hossain and Mizutani [1] reported that in pruning treatments conducted on 9-year-old "Akatsuki" peach varieties budding on strong rootstock in 2001-2005 TA value decreased in trees with SP more than the decrease in those with WP. Decreased titratable acidity following pruning treatment probably was related to increased light penetration into the center of the trees. Furthermore, Hossain et al. [40] reported that SSC was higher and TA was lower in summer-pruned than in winterpruned peach trees. Bayazit et al. [3] reported in a study conducted on peach and nectarine varieties that SP has no effect on SSC, pH, and TA values of fruits.

Carbohydrates are an essential source of reserve energy in temperate zone trees and other perennial plants. They can be mobilized for metabolism or translocated to other plant organs. The concentration and localization of carbohydrates, such as sugars and starches, within tissues are affected by many factors, such as temperature, moisture, light, pruning, and time of planting [20]. As can be seen in Table 4, it was found that, in pruning treatments conducted on two early season peach varieties, trees in control and WP treatment had highest values in terms of both starch and total extracted carbohydrate contents. The late SP had higher values in terms of similar carbohydrate components compared to those with early SP.

In SP treatments conducted on plenty of fruit varieties, many researchers reported that shoot reenlargement was observed in trees with early SP as to compensate decreasing leaf areas. Due to the shoot reenlargement on trees, decreases were observed in stored carbohydrates of trees. Lang [43] 
reported that SP conducted until harvest resulted in the decrease in storage reserves of trees to be used in following periods. Demirtaş et al. [44] conducted 5 different SP and WP treatments on "Hacihaliloğlu" apricot trees and found that postharvest SP treatment has the highest increasing effect on average total sugar, reducing sugar, and starch contents. In sweet cherry, one year after SP, the level of carbohydrate in trunk was lower compared to unpruned trees [12]. Other studies have also shown that pruning results in quantitative changes in carbohydrate reserves. Pruning affects the concentration of reserves, by elimination of carbohydrate storage sites [18].

The results that we obtained about peach varieties related to carbohydrate contents are completely compatible with the findings of Stutte et al. [45], Danielle et al. [46], and İkinci [7] who studied on apple, cherry, apricot, and peach varieties.

\section{Conclusion}

Pruning treatments performed on some temperate climate fruit varieties such as peach suggested that SP decreases tree length, improves fruit quality, thanks to better sunshine in tree crown, significantly increases marketable fruit percentage, and improves enhanced flower bud formation. As it is anticipated, peach agriculture will be improved in Şanlıurfa province in the near future. The focal point of this research was to control tree growth with pruning and obtain higher quality fruits.

The present study suggested that SP decreased shoot length, increased shoot diameter enlargement, decreased fruit yield, and increased fruit weight; and on condition that SP treatment is applied each year, SSC increased significantly and TA amount decreased. Preharvest summer pruning obviously promotes fruit maturation when compared to unpruned trees during the season of pruning. In addition, it was found that, in peach trees with SP, carbohydrate content significantly decreased compared to trees in control and only WP and this decrease was observed in preharvest SP treatment mostly.

We found that marketable fruit yields of trees with SP increased significantly, fruits got more colorful, and an observable increase was found in leaf area after 1-2 months of pruning treatments. Preharvest SP treatments on peach bring partial damages to fruits on trees. The effect of pruning treatments on tree and fruit quality can be observed within the next session. Our experience indicates that peach growers should consider SP as a standard cultural technique in the development of peach trees.

\section{Conflict of Interests}

The author has declared that no competing interests exist.

\section{Acknowledgment}

The author thanks Professor Dr. Ahmet Ruhi Mermut (Department of Soil Science) for critical reading of the paper and valuable comments and recommendations on the paper.

\section{References}

[1] A. B. M. S. Hossain and F. Mizutani, "Dwarfing peach trees and fruit quality development by using summer pruning as physiological changed dwarfing component," Australian Journal of Basic and Applied Sciences, vol. 2, pp. 844-849, 2008.

[2] A. Erez, "Dwarfing peaches by pruning and by paclobutrazol," Acta Horticulturae, vol. 146, pp. 235-241, 1984.

[3] S. Bayazit, B. İmrak, and A. Küden, "Effects of tipping applications on yield and fruit quality of some peach and nectarine," Mustafa Kemal Üniversitesi, Ziraat Fakültesi Dergisi, vol. 17, pp. 23-30, 2012.

[4] K. R. Day, T. M. Dejong, and A. A. Hewitt, "Postharvest summer pruning of "Firebrite" nectarine trees," HortScience, vol. 24, pp. 238-240, 1989 .

[5] M. N. Demirtaş, Bolat I, S. Ercişli et al., "The effects of different pruning treatments on the growth, fruit quality and yield of "Hacihaliloglu" apricot," Acta Scientiarum Polonorum: Hortorum Cultus, vol. 9, pp. 183-192, 2010.

[6] A. B. M. S. Hossain, F. Mizutani, J. M. Onguso, A. R. El-Shereif, and K. L. Rutto, "Effect of summer pruning on shoot growth and fruit quality in peach trees trained as slender spindle bush type," Bulletin of the Faculty of Agriculture, Ehime University, vol. 51, pp. 9-13, 2006.

[7] A. İkinci, The effect different pruning treatments on yield, quality and carbohydrate accumulation in peach, almond and apricot [Ph.D. thesis], Cukurova University, 1999.

[8] G. Tehrani and S. J. Leuty, "Influence of rootstock and pruning on productivity, growth, and fruit size of European plum cultivars," Journal of the American Society for Horticultural Science, vol. 112, pp. 743-747, 1987.

[9] F. Mizutani, T. Kogami, D. G. Moon, R. C. Bhusal, K. L. Rutto, and H. Akiyoshi, "Effects of summer pruning on the number of apical buds near the trunk in slender-spindle trained apple trees grafted on semi-dwarfing rootstocks," Bulletin of the Experimental Farm College of Agriculture, Ehime University, vol. 22, pp. 1-10, 2000.

[10] S. S. Miller, "Regrowth, flowering and fruit quality of "delicious" apple trees as influenced by summer pruning," Journal of the American Society for Horticultural Science, vol. 107, pp. 975-978, 1982.

[11] R. P. Marini, "Defoliation, flower bud cold hardiness, and bloom date of peach as influenced by pruning treatments," Journal of the American Society for Horticultural Science, vol. 113, pp. 391394, 1986.

[12] D. Clair-Maczulajtys, C. Sarthou, and G. Bory, "Effects of pruning on carbohydrate distribution in the trunk of sweet cherry (Prunus avium L.)," Scientia Horticulturae, vol. 59, no. 1, pp. 61-67, 1994.

[13] S. C. Myers, "Preharvest waterspout removal influences canopy light relations, fruit quality, and flower bud formation of "Redskin" peach trees," Journal of the American Society for Horticultural Science, vol. 118, pp. 442-445, 1993.

[14] R. P. Marini, "Vegetative growth, yield, and fruit quality of peach as influenced by dormant pruning, summer pruning, and summer topping," Journal of the American Society for Horticultural Science, vol. 110, pp. 133-139, 1985.

[15] J. Niran, Effects of Time of Pruning on Some Characteristics of Peach (Prunus persica L.) cvs. Flordabelle and Flordasun, Graduate School, Kasetsart University, Bangkok, Thailand, 1981.

[16] M. Satoh and K. Ohyama, "Studies on photosynthesis and translocation of photosynthate in mulberry tree. VI. Changes 
in amylase activity and in amount of carbohydrates in a storage organ after shoot pruning," Japanese Journal of Crop Science, vol. 46, pp. 499-503, 1977.

[17] A. Moing, B. Lafargue, J. M. Lespinasse, and J. P. Gaudillere, "Carbon and nitrogen reserves in prune tree shoots: effect of training system," Scientia Horticulturae, vol. 57, no. 1-2, pp. 99110, 1994.

[18] G. Bory and D. Clair-Maczulajtys, "Reserve metabolites: an insight into tree physiology," in Physiologie des Arbres et Arbustes en Zones Arides et Semi-Arides, A. Riedacker, E. Dreyer, C. Pafdadnam, and G. Bory, Eds., pp. 97-115, John Libbey Eurotext, Amilly, France, 1993.

[19] L. Reich, "Carbohydrate in the apple tree: effects associated with pruning and deblossoming," HortScience, vol. 20, pp. 238-240, 1985.

[20] J. Daie, "Carbohydrate partitioning and metabolism in crops," Horticultural Reviews, vol. 7, pp. 69-108, 1985.

[21] Anonymous, "Eğirdir fruit research station management," Soil Analysis Report Results, 2008.

[22] S. S. Miller, "Summer pruning affects fruit quality and light penetration in young peach trees," HortScience, vol. 22, pp. 390393, 1987.

[23] A. Küden and N. Kaşka, "Effects of winter and summer pruning on the yield and fruit quality of "Priana" and "Beliana" apricot cultivars," Acta Horticulturae, vol. 384, pp. 455-459, 1995.

[24] M. Kaplankıran, The relationships between citrus rootstocks growth and phytohormone, minerals and carbohydrate content [Ph.D. thesis], Cukurova University, 1984.

[25] B. H. Taylor and D. C. Ferree, "The influence of summer pruning and cropping on growth and fruiting of apple," Journal of the American Society for Horticultural Science, vol. 109, pp. 19-24, 1984.

[26] F. Kappel and M. Bouthillier, "Rootstock, severity of dormant pruning, and summer pruning influences on peach tree size, yield, and fruit quality," Canadian Journal of Plant Science, vol. 75, no. 2, pp. 491-496, 1995.

[27] D. C. Elfving, "Growth and fruiting responses of vigorous apple branches to pruning and branch orientation treatments," Journal of the American Society for Horticultural Science, vol. 101, pp. 290-293, 1976.

[28] C. R. Rom and D. C. Ferree, "Time and severity of summer pruning influences on young peach tree net photosynthesis, transpiration, and dry weight distribution," Journal of the American Society for Horticultural Science, vol. 110, pp. 455-461, 1985.

[29] A. Mika and M. Piątkowski, "Controlling tree size in dense plantings by winter and summer pruning," Acta Horticulturae, vol. 43, pp. 95-102, 1989.

[30] I. Platon and L. Zagrai, "The influence of training system and pruning time on growth and apple fruiting," Acta Horticulturae, vol. 451, pp. 513-518, 1997.

[31] D. W. Greene and W. J. Lord, "Effects of dormant pruning, scoring and growth regulators on growth, yield and fruit quality of "delicious" and "cortland" apple trees," Journal of the American Society for Horticultural Science, vol. 108, pp. 590-595, 1983.

[32] B. S. Daulta, S. Devi, and D. Sing, "Effect of severity pruning on yield and quality of peach cv. Sharbati," Indian Journal of Horticulture, vol. 43, pp. 180-183, 1986.

[33] S. D. Chitkara, R. K. Arora, and R. K. Sharma, "Effect of various levels of pruning on yield and fruit quality in Flordasun peach,"
Haryana Journal of Horticultural Sciences, vol. 20, pp. 189-192, 1991.

[34] M. E. Akçay, "The effect of pruning on growth, yield and quality in sweet cherries," in Proceedings of the 1st Stone Fruits Symposium, pp. 153-159, Yalova, Turkey, 2001.

[35] D. J. Chalmers and B. A. van den Ende, "Reappraisal of the growth and development of peach fruit," Australian Journal of Plant Physiology, vol. 2, no. 4, pp. 623-634, 1975.

[36] D. J. Chalmers, R. L. Canterford, P. H. Jerie, T. R. Jones, and T. D. Ugalde, "Photosynthesis in relation to growth and distribution of fruit in peach trees," Australian Journal of Plant Physiology, vol. 2, no. 4, pp. 635-645, 1975.

[37] C. S. Walsh, F. J. Alnutt, A. N. Miller, and A. H. Thompson, "Nitrogen level and time of mechanized summer shearing influence long-term performance of a high-density "Redskin" peach orchard," Journal of the American Society for Horticultural Science, vol. 114, pp. 373-377, 1989.

[38] A. Mika, "Physiological responses of fruit trees to pruning," Horticultural Reviews, vol. 8, pp. 337-378, 1986.

[39] İ. Gür and L. Prrlak, "Determination of phonological and pomological characters of some peach cultivars grown in Eğirdir ecological conditions," Batı Akdeniz Tarımsal Araştırma Enstitüsü Derim Dergisi, vol. 28, pp. 27-41, 2011.

[40] A. B. M. S. Hossain, F. Mizutani, and J. M. Onguso, "Effect of summer pruning on maintaining the shape of slender spindle bush of peach tree grafted on vigorous rootstock," Journal of the Japanese Society of Agricultural Technology Management, vol. 11, no. 2, pp. 55-62, 2004.

[41] R. P. Marini and J. A. Barden, "Growth and flowering of vigorous apple trees as affected by summer or dormant pruning," Journal of the American Society for Horticultural Science, vol. 107, pp. 3439, 1982.

[42] C. R. Cust and D. C. Ferree, "Time and severity of summer pruning influences on young peach tree net photosynthesis, transpiration, and dry weight distribution," Journal of the American Society for Horticultural Science, vol. 110, pp. 455-461, 1985.

[43] G. A. Lang, "Underlying principles of high density sweet cherry production," Acta Horticulturae, vol. 667, pp. 325-333, 2005.

[44] M. N. Demirtaş, Bolat İ, S. Ercişli et al., "The effects of different pruning treatments on seasonal variation of carbohydrates in "Hacihaliloglu" apricot cultivar," Notulae Botanicae Horti Agrobotanici Cluj, vol. 38, pp. 223-227, 2010.

[45] G. W. Stutte, T. A. Baugher, S. P. Walter, D. W. Leach, D. M. Glenn, and T. J. Tworkoski, "Rootstock and training system affect dry-matter and carbohydrate distribution in "golden delicious" apple trees," Journal of the American Society for Horticultural Science, vol. 119, no. 3, pp. 492-497, 1994.

[46] D. Clair-Maczulajtys, C. Sarthou, and G. Bory, "Effects of pruning on carbohydrate distribution in the trunk of sweet cherry (Prunus avium L.)," Scientia Horticulturae, vol. 59, no. 1, pp. 61-67, 1994. 


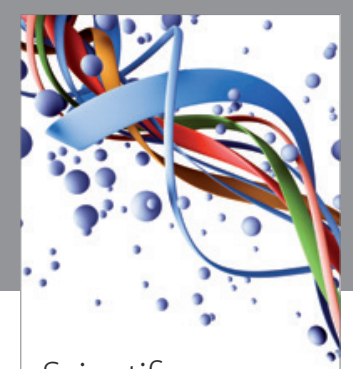

Scientifica
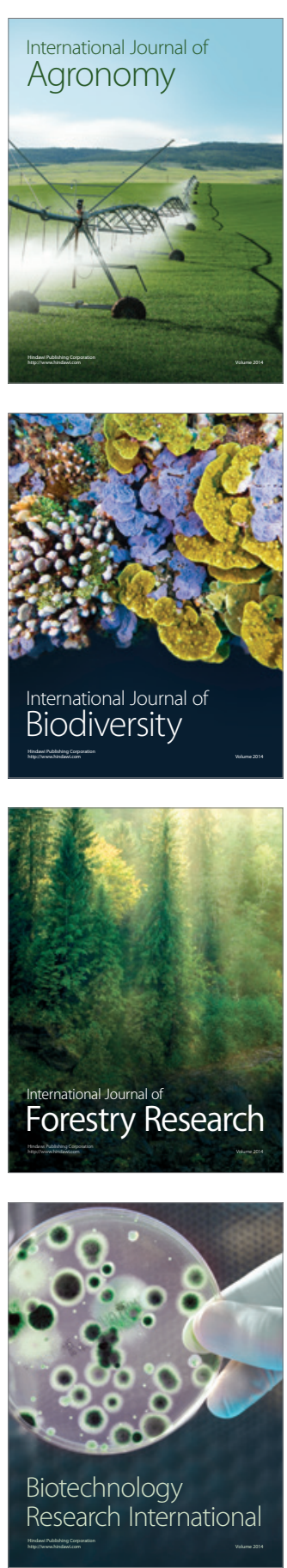
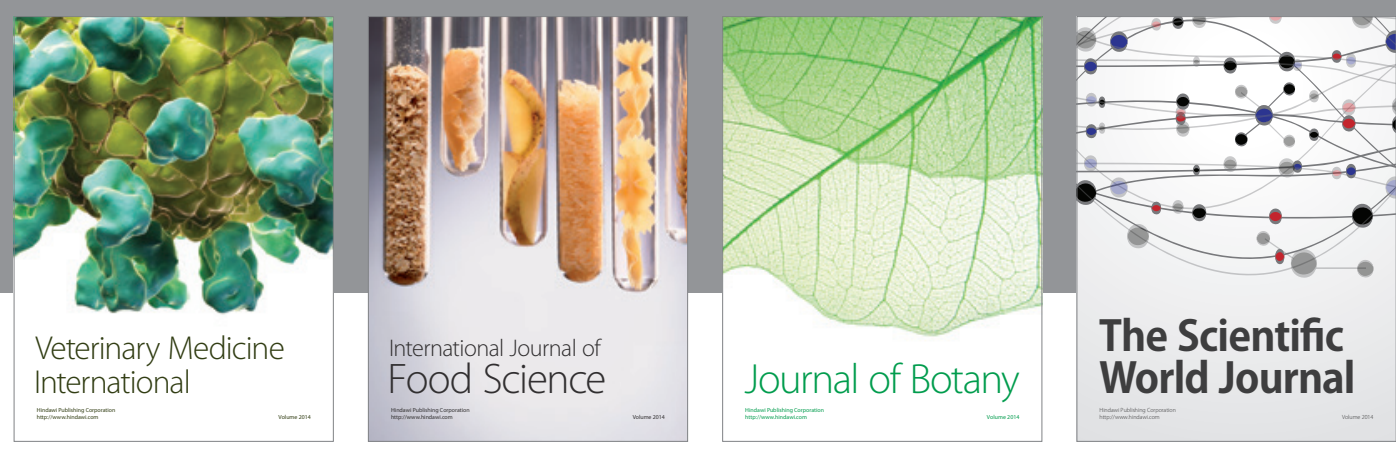

The Scientific World Journal
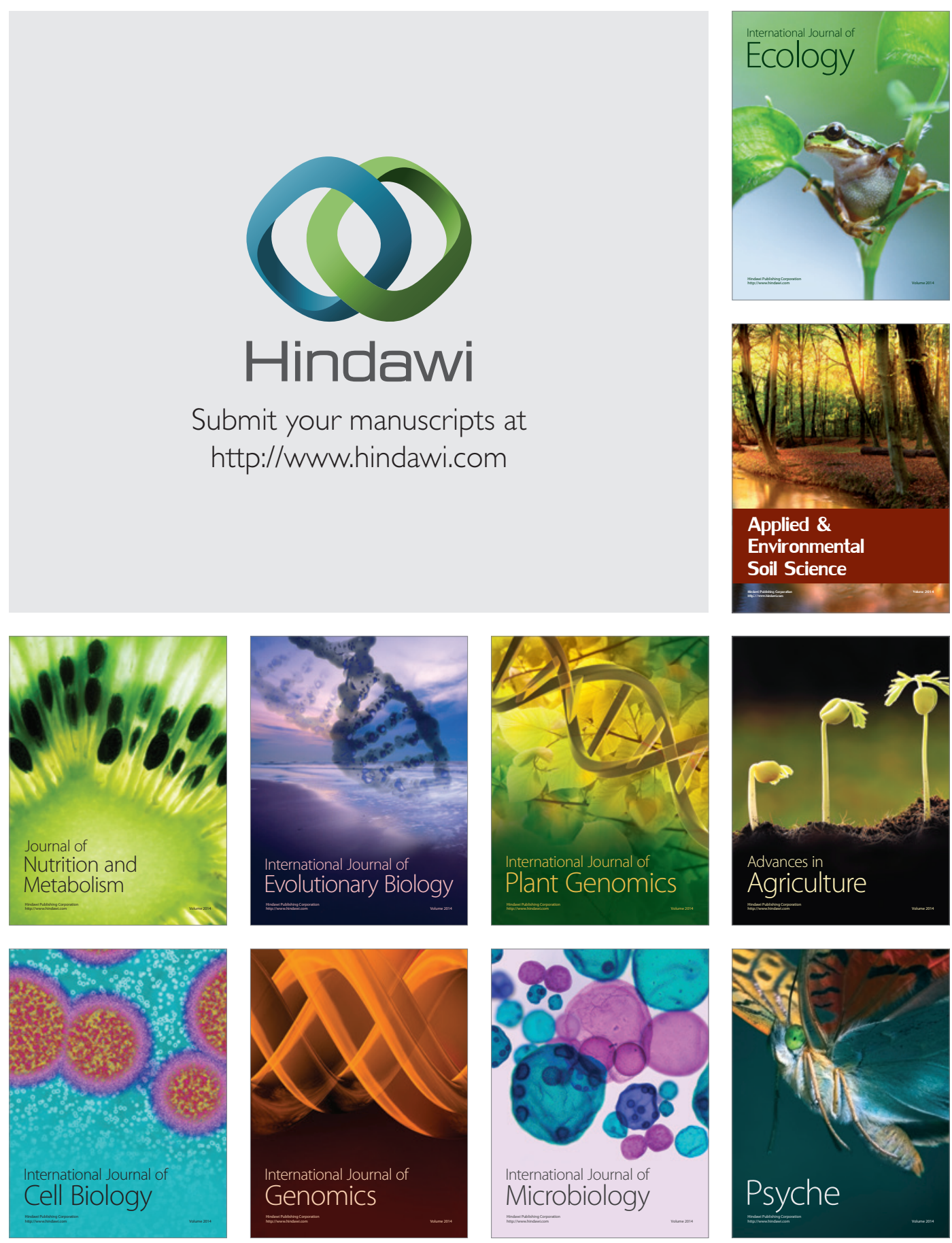